\title{
触 New Disease Reports \\ First report of Bell pepper mottle virus infecting Calibrachoa in Germany
}

W. Menzel ${ }^{1} *$ S. Winter ${ }^{1}$, J. Hamacher ${ }^{2}$ and M. Heupel ${ }^{3}$

${ }^{1}$ Leibniz Institute DSMZ - German Collection of Microorganisms and Cell Cultures, Plant Virus Department, Inhoffenstraße 7 B, 38124 Braunschweig, Germany; ${ }^{2}$ University of Bonn, Department of Phytomedicine, Institute of Crop Science and Resource Conservation, Nußallee 9, 53115 Bonn, Germany; ${ }^{3}$ Landwirtschaftskammer Nordrhein-Westfalen, Pflanzenschutzdienst, Gartenstrasse 11, 50765 Köln-Auweiler, Germany

*E-mail: wulf.menzel@dsmz.de

Received: 12 Apr 2019. Published: 08 May 2019. Keywords: BPeMV, North Rhine-Westphalia, Solanaceae, Tobamovirus.

Varieties of Calibrachoa, a genus of plants with petunia-like flowers in the Solanaceae family originating from South America, are becoming increasingly popular as bedding and balcony plants worldwide. In autumn 2018, chlorotic spots and vein chlorosis were observed on several plants in the greenhouse of a nursery in North-Rhine Westphalia, Germany (Fig. 1) where only calibrachoa is cultivated. From the first mild symptoms, a severe disease developed with necrosis of leaves and wilting of entire shoots (Fig. 2). Almost all plants in the glasshouse (c. $2000 \mathrm{~m}^{2}$ ) became infected rapidly leading to the total loss of the crop.

Investigations by electron microscopy showed the presence of rod-shaped virus-like particles (Fig. 3) indicative of tobamoviruses. This was confirmed by RT-PCR in samples from twelve randomly collected plants using a generic primer pair for the detection of tobamoviruses (Menzel $e t$ al., 2019). Two PCR products were sequenced directly in the forward and reverse directions (HZI, Braunschweig) revealing 100\% sequence identity. Sequence comparison using blastn showed $98.7 \%$ nucleotide sequence identity to Bell pepper mottle virus (BPeMV, genus Tobamovirus; GenBank Accession No. NC_009642) and $75.8 \%$ identity to Tomato mottle mosaic virus (KX898034). BPeMV was first described in the 1960's as an unusual strain of Tobacco mosaic virus infecting pepper in Argentina (Garcia et al., 1968). Wetter et al. (1987) later characterised it as a distinct virus species that led to lethal infections in inoculated Petunia hybrids. The complete genome sequence for BPeMV reported by Rhie et al. in 2007 confirmed this status.

The calibrachoa isolate of BPeMV showed a strong serological reaction in ELISA using a BPeMV-specific antibody raised against an eggplant isolate of this virus (DSMZ AS-0244). In Europe, its occurrence is documented

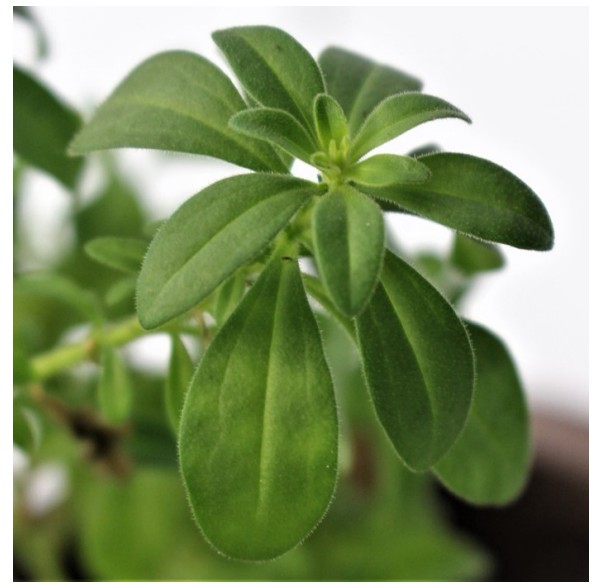

Figure 1 only once from the Netherlands in 1980 (Tobias et al., 1982). The pathway of introduction of this obviously rarely occurring virus into the vegetatively propagated calibrachoa plants is so far unknown. This is the first evidence of the occurrence of BPeMV in Germany, and the first proof that it is infectious in an ornamental plant. Due to the economic importance of the ornamental host Calibrachoa, and the fast and fatal progression of the disease, the occurrence of similar symptoms in these plant cultures demands careful monitoring and early diagnosis. The BPeMV isolate from calibrachoa (MK770674) was deposited as PV-1239 in the DSMZ Plant Virus Collection.

\section{References}

Gracia O, Feldman JM, Pontis RE, Boninsegna J, 1968. Some viruses affecting tomatoes and peppers in Argentina. Plant Disease Reporter 52 674-676.

Menzel W, Knierim D, Winter S, Hamacher J, Heupel M, 2019. First report of Tomato brown rugose fruit virus infecting tomato in Germany. New Disease Reports 39, 1.

http://dx.doi.org/10.5197/j.2044-0588.2019.039.001

Rhie MJ, Min BE, Hong JS, Song YS, Ryu KH, 2007. Complete genome sequence supports Bell pepper mottle virus as a species of the genus Tobamovirus. Archives of Virology 152, 1401-1407. http://dx.doi.org/10.1007/s00705-007-0950-0

Wetter C, Dore I, Bernard M, 1987. Bell pepper mottle virus, a distinct tobamovirus infecting pepper. Journal of Phytopathology 119, 333-344. http://dx.doi.org/10.1111/j.1439-0434.1987.tb04404.x 